\title{
Conservation Problems on Tristan da Cunha
}

\author{
By J. H. Flint
}

The author spent two years, 1963-65, as schoolmaster on Tristan da Cunha, during which he spent four weeks on Nightingale Island. On the main island he found that bird stocks were being depleted and the islanders taking too many eggs and young; on Nightingale, however, where there are over two million pairs of great shearwaters, the harvest of these birds could be greater. Inaccessible Island, which like Nightingale, is without cats, dogs or rats, should be declared a wildlife sanctuary.

WHEN the first permanent settlers came to Tristan da Cunha in the early years of the nineteenth century they found an island rich in bird and sea mammal life. "The mountains are covered with Albatross Mellahs Petrels Seahens, etc.," wrote Jonathan Lambert in 1811 , and Midshipman Greene, who stayed on the island in 1816, recorded in his diary "Sea Elephants herding together in immense numbers." Today the picture is greatly changed. A century and a half of human habitation has drastically reduced the larger, edible species, and the accidental introduction of rats from a shipwreck in 1882 accelerated the birds' decline on the main island. Wood-cutting, grazing by domestic stock and, more recently, fumes from the volcano have destroyed much of the natural vegetation near the settlement, and two bird subspecies, a bunting and a flightless moorhen, have become extinct on the main island.

Curiously, one is liable to see more birds on the day of arrival than in several weeks ashore. When I first saw Tristan from the decks of M.V. Bornholm in November, 1963, there were about fifty albatrosses of three different species circling round the ship on broad wings, or squabbling on the water for scraps of floating rubbish. With them flew skuas, terns, noddies, and two birds of the far south, the Cape pigeon and the silver-grey petrel. In our wake followed two species of storm petrel and the stiff-winged shearwaters of the southern oceans. The sight was promising for my two years' residence on the island. Once ashore, however, most of the birds disappeared. Only a solitary skua haunted the village, and a few terns fed near the landing beach, resting on the jagged cliff of new lava where it met the sea. We found later that it was the ships which attracted the larger birds, while the smaller species found their food in the plankton-rich water offshore, and were rarely visible from the land. Once Bornholm sailed Tristan became almost birdless.

Occasionally we saw yellow-nosed and sooty albatrosses flying over the settlement, but rarely at close quarters, and to get a nearer view 
we had to scramble up to the "base," a wilderness plateau of bogs and waist-high tree fern, 2000 feet above the settlement plain, where the birds nest. They lay their single eggs on towers of trampled mud, a foot high, and registered their resentment at our intrusion by clapping their bills; but they made no attempt to fly away, so that they are an easy prey for a hungry islander. One of the older men observed that the mollies (yellow-nosed albatross) were more plentiful than they had been for many years - the eruption and evacuation of the settlement had given their numbers a chance to recover. Two years later, however, occupied nests were noticably fewer on the settlement side of the island. A limit is imposed on the number of mollies taken for food on the main island, but enforcement is difficult, and the quota is rarely observed. The number varies, but in 1965 it was in the region of four hundred birds. In theory no young are taken from the southeast quarter of the base and eggs are not collected.

\section{Penguins and Prions}

The rockhopper penguin, once abundant, is now restricted to two small rookeries far from the settlement, though the birds come ashore there to moult. One spent a foodless month beside a village dustbin growing daily more dishevelled. The wandering albatross once bred on the barren lava peak of the island and some islanders still remember seeing nests. Today a remnant breed on little-visited Inaccessible.

Broad-billed prions-nigh'birds to the islanders-are among the commonest species seen from the shore, though they nest in numbers at only one site near the settlement. This is in a cave below the Hillpiece-an extinct volcanic hill between the village and the potato patches-where eggs are still collected and probably few young are reared. On Nightingale the species is very abundant, nesting in natural caves around the coast and in the loose walling of the huts. Returning from Nightingale in a strong wind on September 24, 1965, the boats were accompanied by numbers of prions and at one point passed through a close-packed flock, several thousand strong. Although the Hillpiece colony may be exterminated in time the species generally is in little danger since no eggs are taken from the other islands.

The most characteristic sound of Tristan winter evenings is a high fluting whistle from the edge of the base, two thousand feet above the squat island houses. The calls are those of the long-winged and Schlegel's petrels, rarely seen over the land in daylight, which nest in the southern winter months. In November the islanders hunt their fat young "eglets," using dogs to locate the occupied holes, and, like the albatrosses, they are becoming scarcer year by year. One young long-winged petrel brought to me by an islander was reared on a mixture of raw fish and bloater paste. When the time came for it to fly it refused all food, probably a contributory factor in the desertion by the parents for which most petrels are noted and an observation that could easily be checked by further experiment.

In addition to a dozen breeding species of sea birds the main island 
of Tristan has one resident land bird-a thrush, called by the islanders the "starchy." Close to the European song thrush in appearance, the bird is still fairly common on the base but rarely seen near the settlement, presumably due to the presence of cats since it has little fear of human beings. Non-breeding birds include three fairly frequent visitors from South America-purple gallinule, cattle egret and barn swallow-all no doubt assisted on their 1800-mile journey by the prevailing north-west wind. The gallinule is so frequently seen that it has even acquired an island name-the guttersnake, referring to its sinuous movements through the grass of the wet ditches in which it is usually found. Sometimes four or five are seen together, normally in the greenish juvenile plumage, though one or two purple adults have been recorded. Possibly in time the guttersnake will remain to breed, though the winters may be too severe. Cattle egrets have elsewhere proved outstanding colonisers of new territory, and the swallows seem quite at home on the island, roosting on the cliffs and hawking for food over the beaches.

\section{The Shearwaters on Nightingale}

If Tristan tends to disappoint the visiting ornithologist the neighbouring island of Nightiingale more than compensates. Each summer the islanders in their light canvas boats, cross the twenty-five miles of ocean separating the two, first in September for eggs, later for penguin guano and finally in April for fat. On this last trip they spend up to a fortnight on the island killing, skinning and boiling down young great shearwaters to make cooking oil. The entire world population of this bird breeds in the Tristan group; though thousands are killed annually, it makes little impression on the teeming colony. The breeding population has been estimated at more than two million pairs (Rowan 1952)-mainly on the square mile of Nightingale; in November, when the eggs are laid, all available holes are occupied and many birds are forced to lay on the open ground; according to to the islanders these eggs are not hatched. When I visited the island in September, great rafts of the birds were gathered offshore and flew at dusk over the beds of tussock grass like dust motes in a shaft of sunlight. Although some 5,000 adult shearwaters are taken for food the main purpose of the September visit is to collect penguin and yellow-nosed albatross eggs; in 1965 four boats took an estimated 23,000 penguin and 1,500 albatross eggs. Young albatrosses are killed on later trips and, though no accurate population or predation figures are available, one imagines both species are being over-exploited. The total of eggs and young taken is, however, lower than formerly. M. K. Rowan, writing in 1951, says that "the population at Nightingale could . . . . stand a great deal more exploitation," a view not shared by one island man who, not having been to Nightingale for several years, expressed surprise at the decrease of birds in the "ponds," the open marshy areas where the nesting albatrosses are most easily seen.

Nightingale and Inaccessible have no dogs, cats or rats to menace 
the bird population and the smaller species flourish. The buntings of both islands have evolved into two distinct species, similar in plumage but differing in the bill size. One feeds primarily on the seeds of tussock grass, and the other cracks the extremely hard seeds of the Island tree. Thrushes are common and completely fearless. Until about ten years ago, Inaccessible was stocked with sheep and cattle, but it is now rarely visited. With careful management Nightingale could provide a perpetual source of eggs and meat for the islanders, but their views on conservation are short-sighted and ways of enforcing any limits difficult to find. Clearly the best hope is to educate the inhabitants to appreciate the necessity of regulating the numbers of birds killed, but it promises to be a long process. I had considerable trouble convincing the children that a barrage of stones was not the best reception for a penguin as it landed on the settlement beach to moult.

In all I was able to spend four weeks on Nightingale during which my main activity was the ringing of 1000 yellow-nosed albatrosses and 500 great shearwaters - a task in which I was greatly assisted by the island men. To date only two have been recovered-an albatross off the South African coast and a shearwater off Newfoundland. These agree with the pattern of recoveries obtained by the Norwegian, Yngvar Hagen, author of the most detailed work on Tristan birds yet published. Whilst ringing the albatrosses I found six birds bearing his rings, one of them ringed as an adult in February, 1938, and therefore at least twenty-eight years old.

The fur seals and sea elephants, once so abundant on Tristan beaches, are now rarely seen. About six sea elephants hauled out near the village during my stay, and although the islanders no longer kill them, they gave them little peace, it being a tradition to chase them back into the sea. There are, however, many secluded beaches around the island and there seems nothing to prevent them from breeding as formerly. One or two pups are said to have been born there in recent years, and N. M. Wace states that five fur seals were born on the main island in 1962, when the islanders were in England. The southern right whales which haunt the shallower seas around the islands in the early spring months, August to October, were greatly reduced in 1963 by the Russian whaling fleet and now appear to number about a dozen adults, though some young ones were seen.

\section{Planning for the Future}

What of the future? If the islanders are to continue enjoying the natural products of their islands a conservation programme is needed. On the main island the taking of eggs and young must be more strictly limited; Nightingale can well be "farmed" but care is needed to see that some birds are not over-exploited, though a heavier annual toll of great shearwater eggs and young could probably be taken without harmful effects. Inaccessible, being difficult to land on and therefore rarely visited, should be declared a reserve where the native mammals 
and birds can survive unmolested. It might also provide a "reservoir" to restock depleted stocks on the other islands, though it seems doubtful if the birds ever move from their home island-a question on which ringing may shed some light.

A programme of controlled harvesting, if the islanders would cooperate, could increase the number of birds on all three islands, and in time Tristan's mountain might once again be covered in birds as it was a century and a half ago.

\section{Scientific Names of Birds, Mammals and Plants Mentioned}

\section{Birds}

Wandering albatross ...

\begin{tabular}{|c|c|}
\hline \multicolumn{2}{|l|}{ 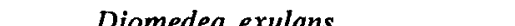 } \\
\hline & Diomedea chlororhynchos \\
\hline$\ldots$ & Phoebetria fusca \\
\hline & Pterodroma macroptera \\
\hline & Pterodroma incerta \\
\hline & Fregetta grallaria \\
\hline & $\begin{array}{l}\text { Priocella (Fulmarus) glacialoides } \\
\text { Procellaria gravis }\end{array}$ \\
\hline$\ldots$ & Daption capensis \\
\hline$\cdots$ & Pachyptila forsteri \\
\hline$\cdots$ & Sterna vittata \\
\hline$\cdots$ & Anous stolidus \\
\hline$\cdots$ & Eudyptes crestatus \\
\hline & Nesospiza spp. \\
\hline & Atlantisia rogersi \\
\hline & $\begin{array}{l}\text { Porphyrula martinica } \\
\text { Ardeola ibis }\end{array}$ \\
\hline & Hirundo rustica erythrogaster \\
\hline
\end{tabular}

Yellow-nosed albatross $\quad \ldots \quad \ldots \quad \ldots \quad$ Diomedea chlororhynchos

Sooty albatross

Long-winged petrel

Schlegel's petrel

Storm petrels ...

Silver-grey petrel

Great shearwater

Broad-billed prio

Skua

Swallow-tailed $\dddot{\text { tern }}$

Brown noddy ....

Rockhopper penguin

Thrush

Inacing . . ... $\ldots$

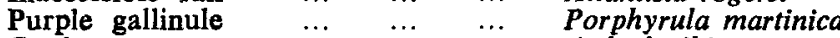

$\begin{array}{llllll}\text { Cattle egret } & \ldots & \ldots & \ldots & \ldots & \text { Ardeola ibis }\end{array}$

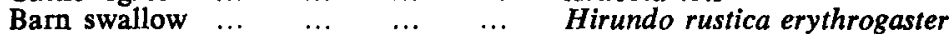

\section{Mammals}

Sea elephant

Fur seal

Southern right whale

... $\quad$... Mirounga leonina

Plants

$\begin{array}{llllll}\text { Island tree } & \ldots & \ldots & \ldots & \ldots & \text { Phylica arborea }\end{array}$

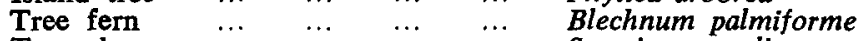

$\begin{array}{llllll}\text { Tussock grass } & \ldots & \ldots & \ldots & \ldots & \text { Spartina arundinacea }\end{array}$

\section{REFERENCES}

ELLIOTT, H. F. I., 1953, The Fauna of Tristan da Cunha, Oryx II, 1; 1962, Tristan da Cunha 1962, Oryx, VI, 4.

HAGEN, Y., 1952, Birds of Tristan da Cunha.

ROWAN, M. K., 1951, The Yellow-nosed Albatross at its breeding grounds in the Tristan da Cunha Group, Ostrich, December, 1954; The Great Shearwater at its breeding grounds. Ibis, 94, 95-121.

WACE, N. M., 1966, Last of the Virgin Islands, Discovery, February, 1966. 


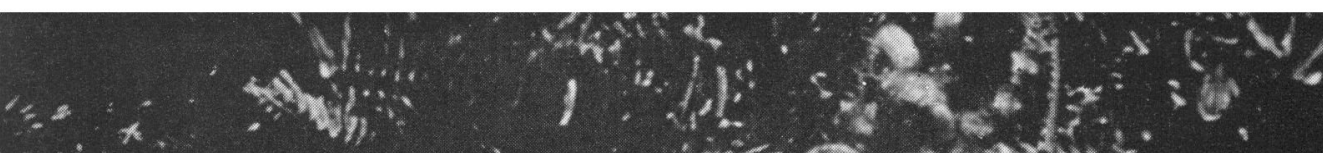

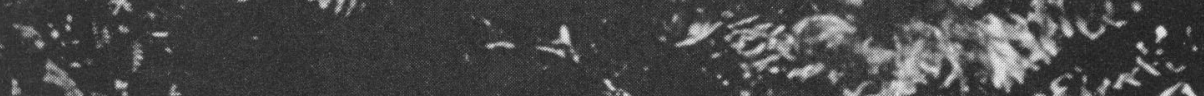

$x^{2}+2 x^{*}: \frac{2}{2}$

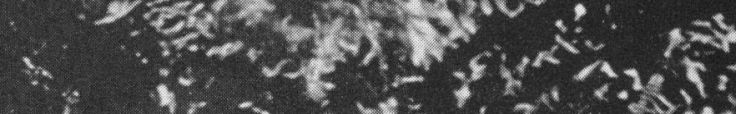

,

i

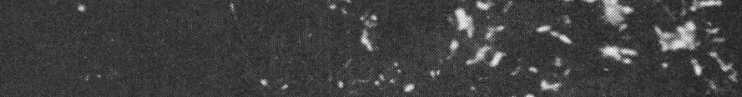

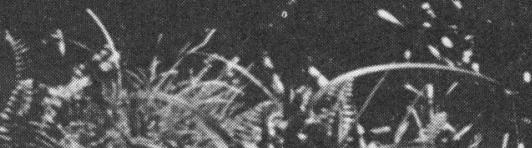

$+3$

$a^{2}$

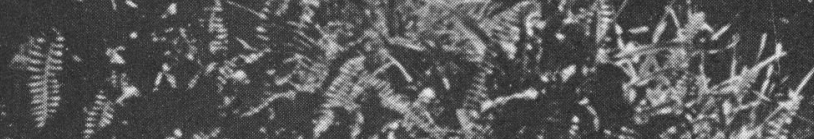

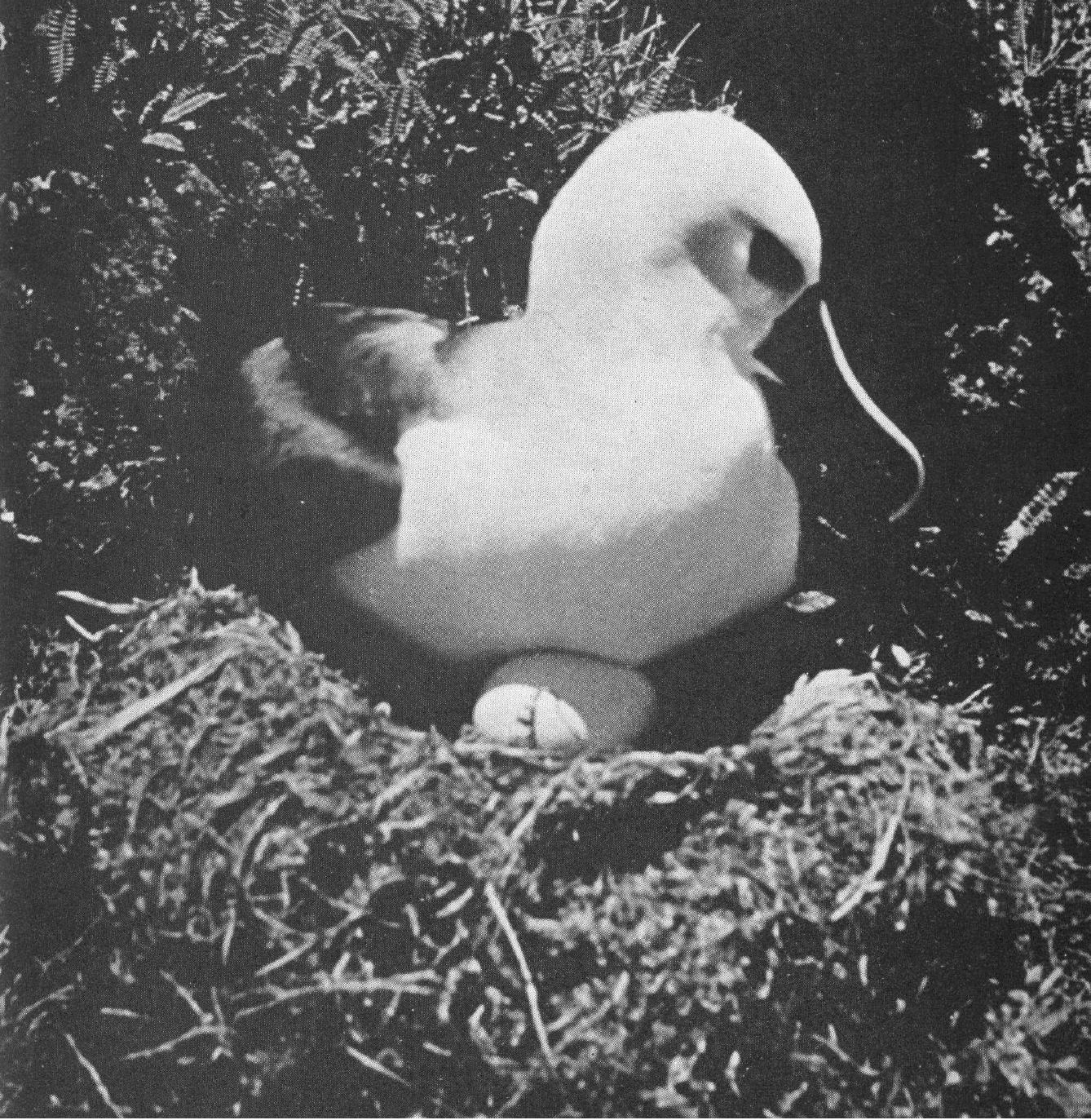

\section{WILDLIFE OF TRISTAN DA CUNHA Photographs by J. H. Flint}

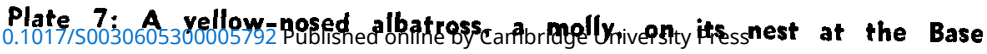


A.
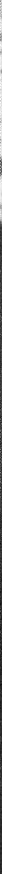

Plate 8: A young male sea elephant which hauled out near the Settlement

Plate 9: Islanders skinning great shearwaters on Nightingale Island in September. They take the meat back salted in wooden kegs

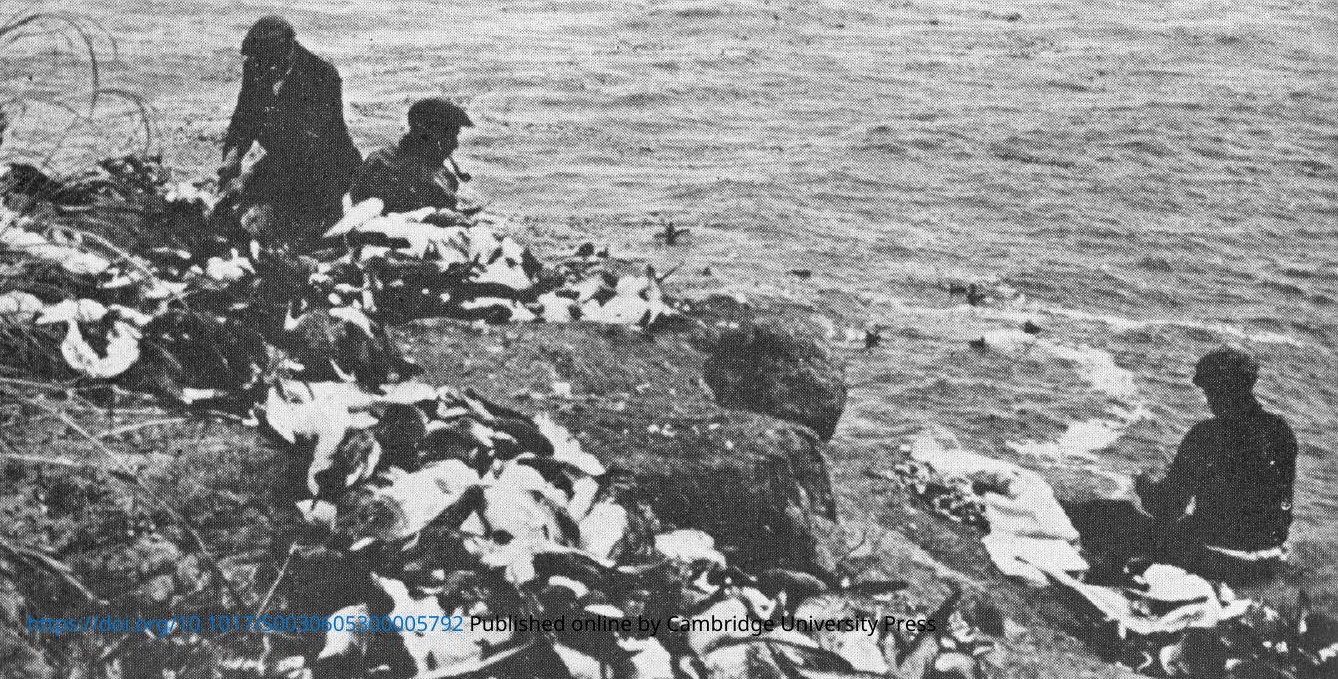


mistint

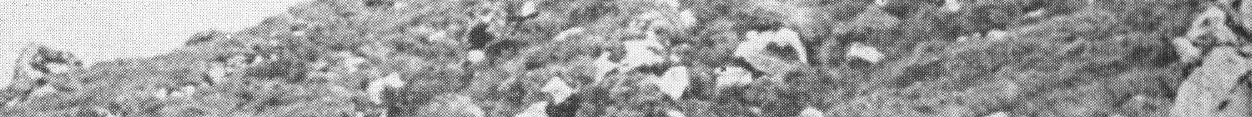

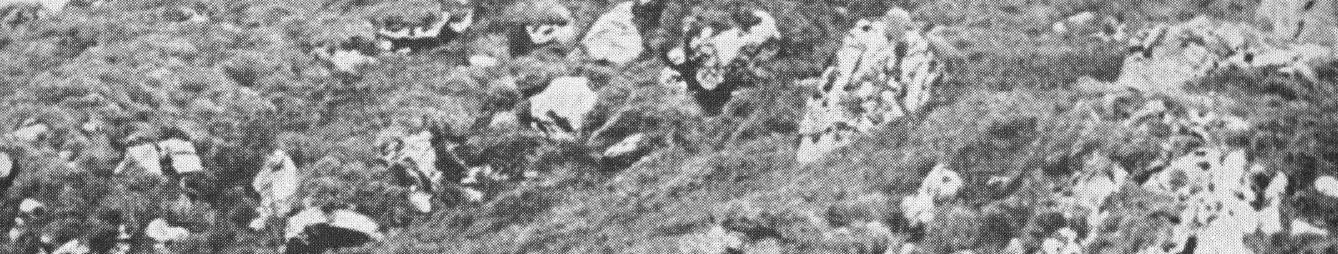

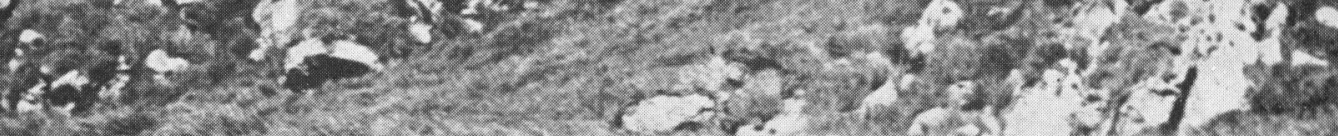

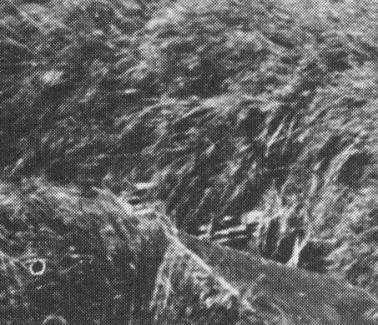

$$
x+r e x+7
$$

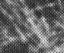

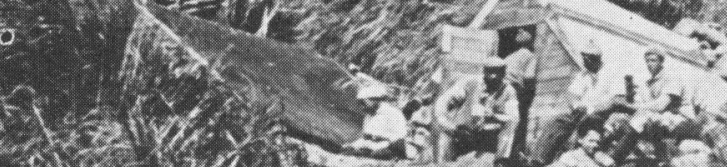
1.

(1) 1 w 3

(1)

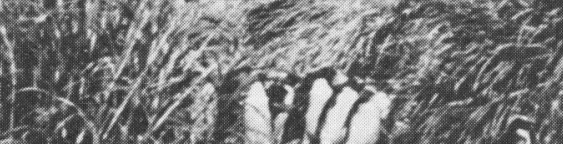

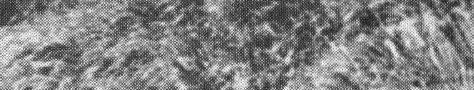

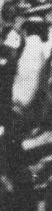

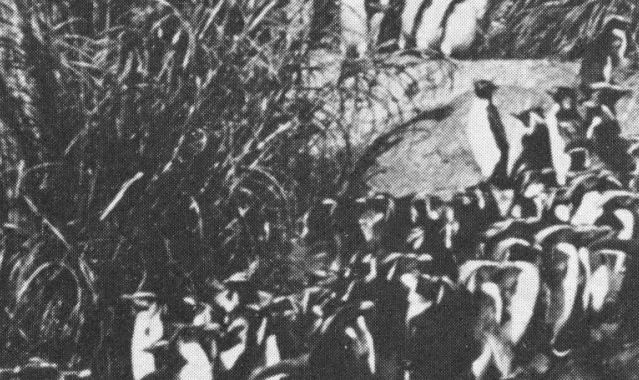

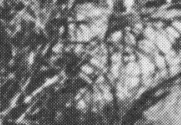

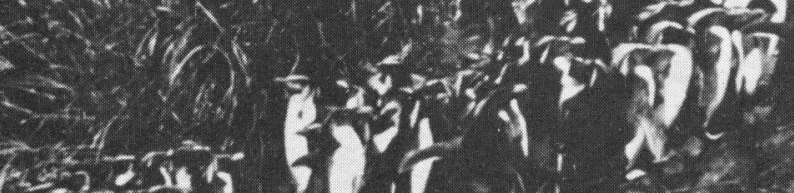




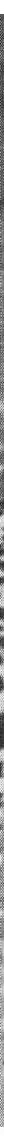

Plate 11: FULL LENGTH: A 


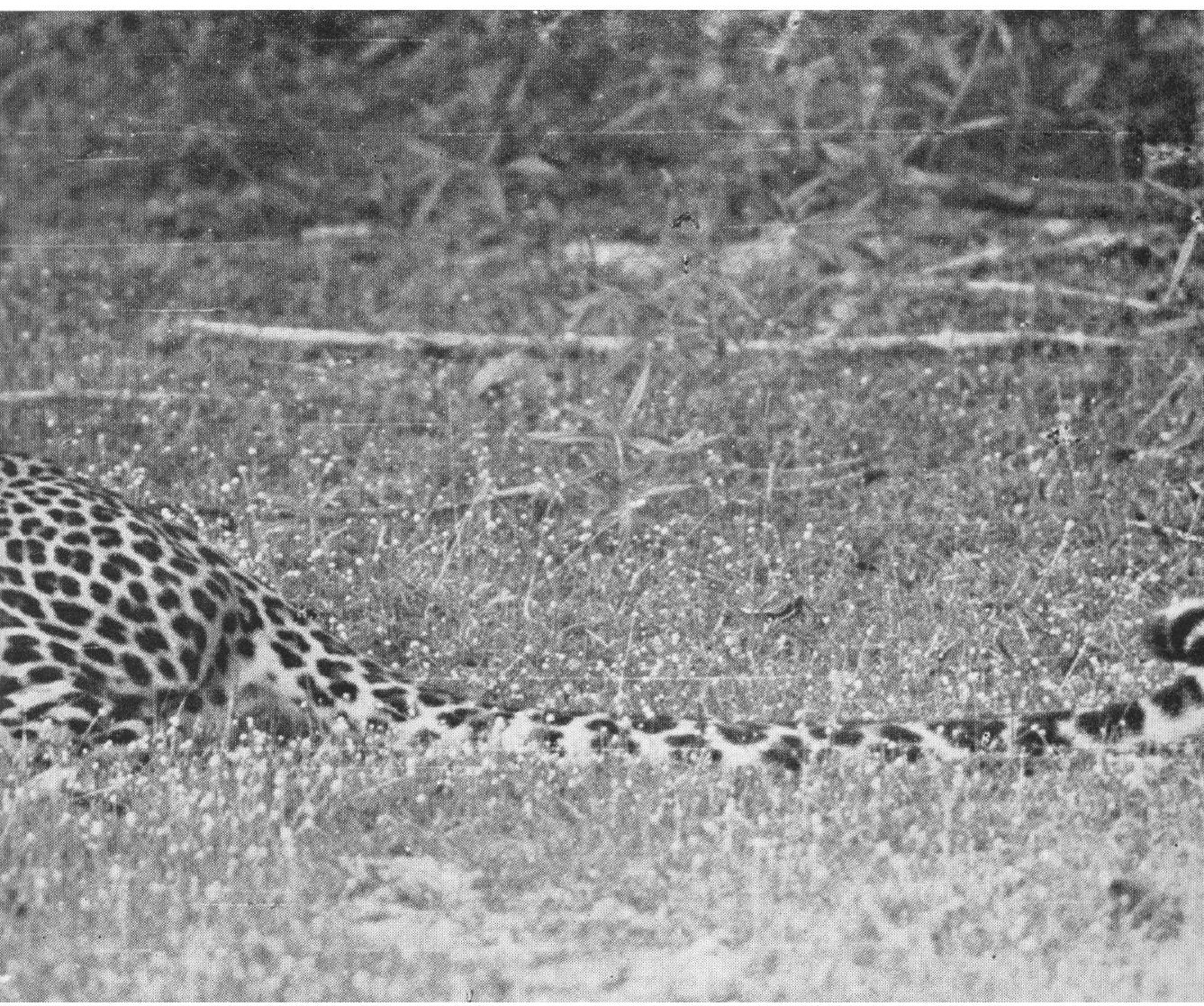

Btudy of a Leopard in Ceylon

Photograph by Mox Hemple 


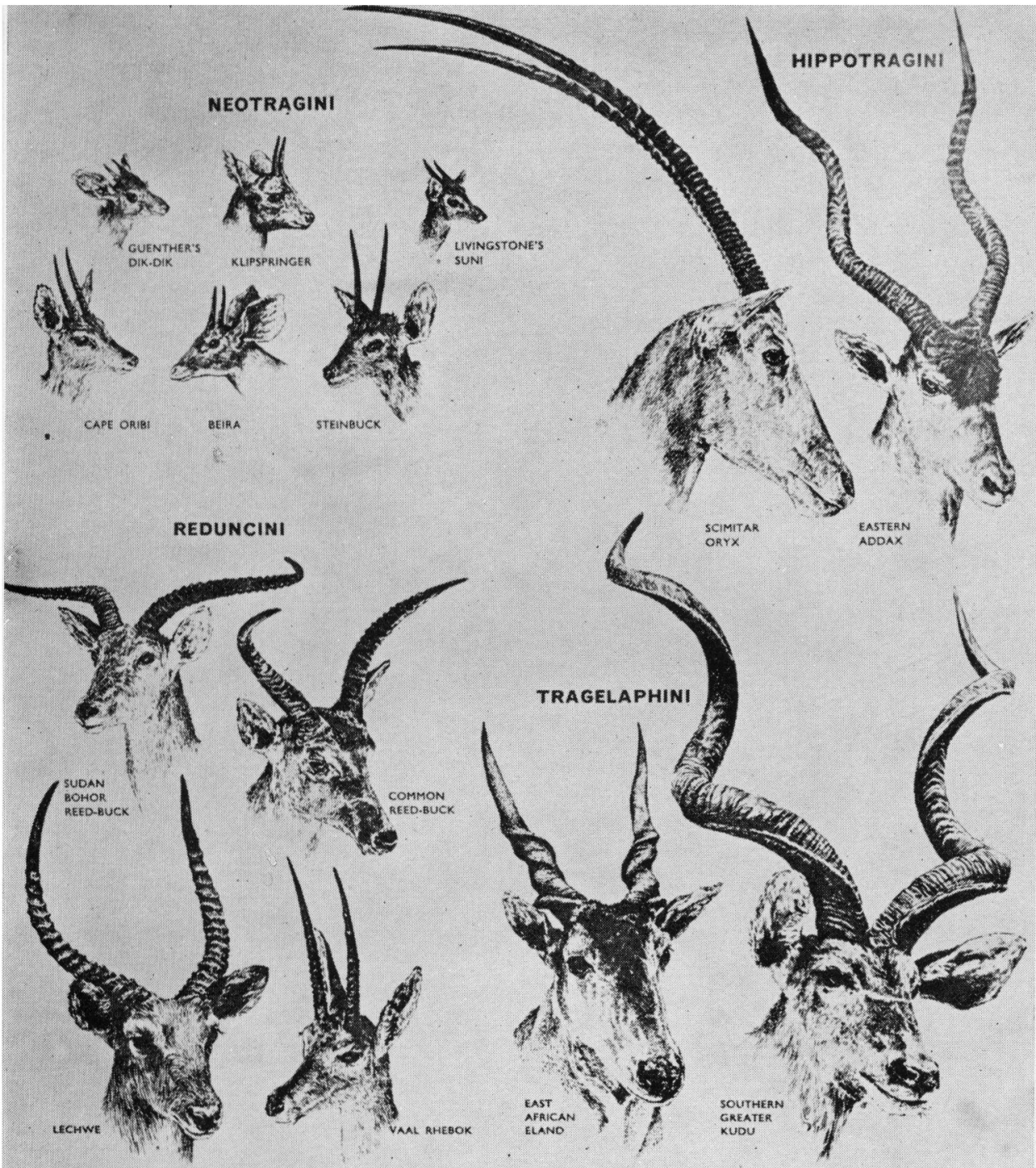

Plate 12: A STUDY IN HORNS. Drawings to illustrate the variety of horns in African antelopes, reproduced by kind permission from The Land and Wildlife of Africa, by Archie Carr, in the Life Nature Library series 


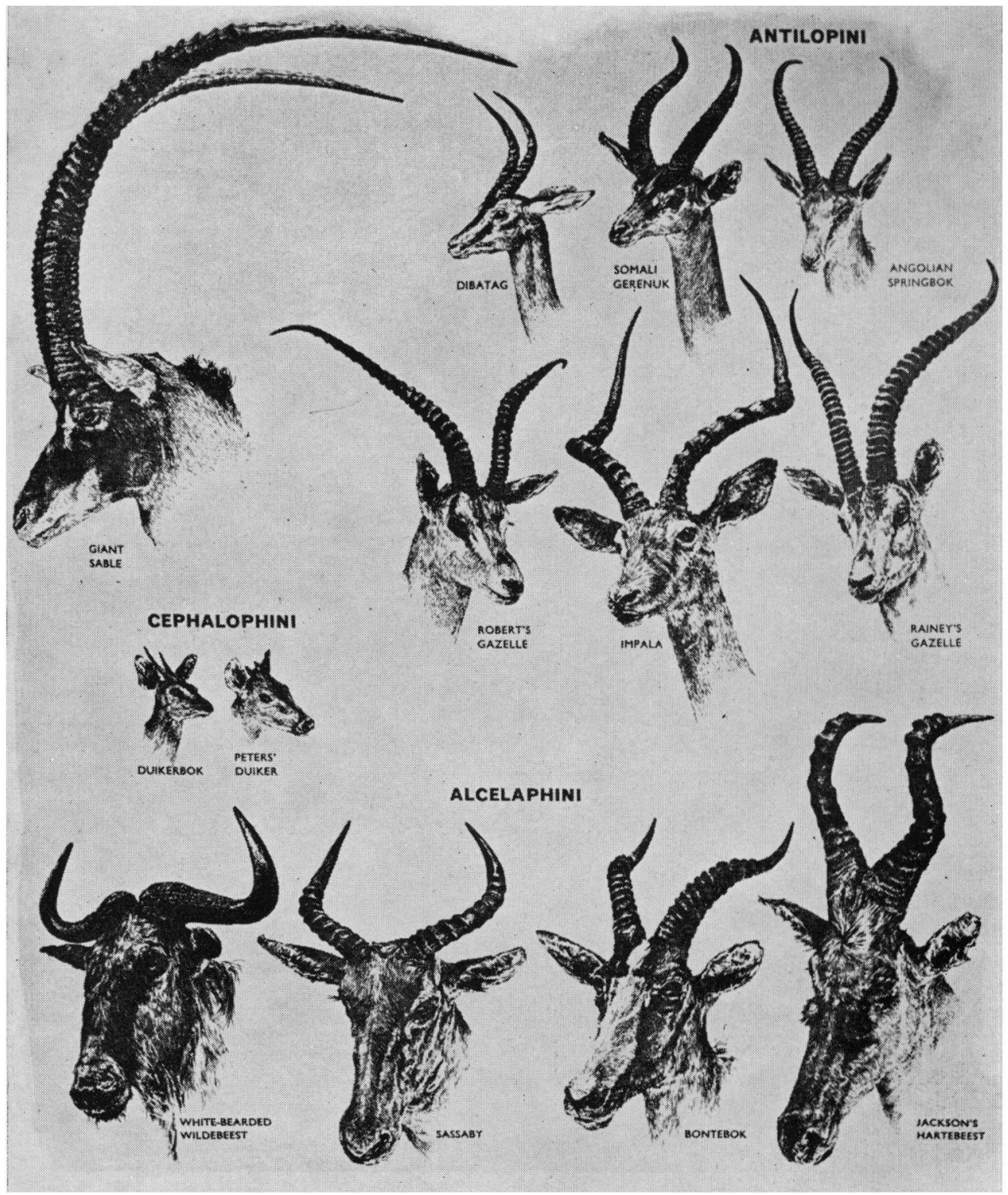




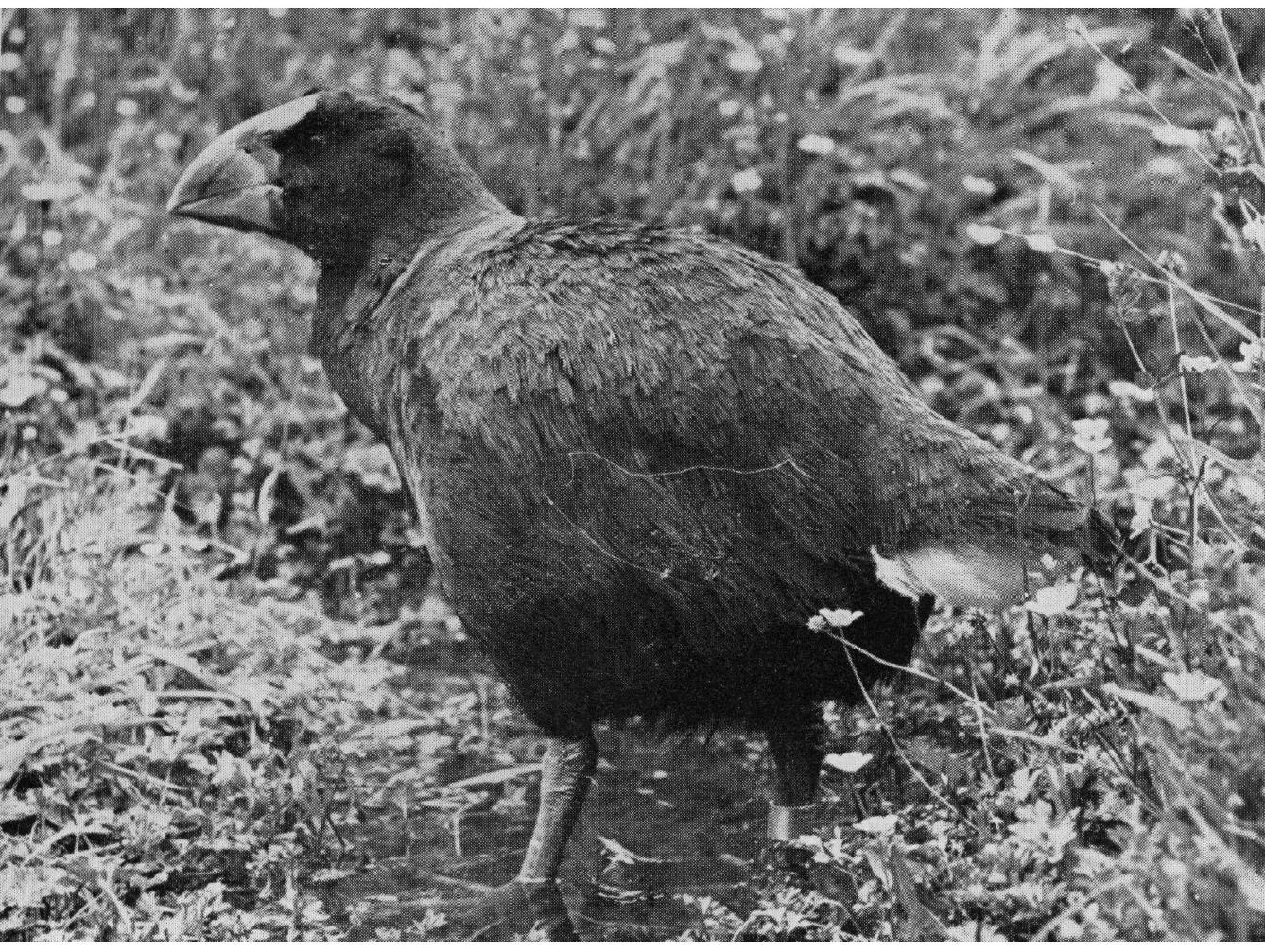

\section{NEW \\ ZEALAND \\ BIRDS}

Plate 13 above: The takahe, the flightless rail rediscovered when it was believed extinct and now guarded in a 700-square-mile Special Area

Plate 14: The kakapo, a bird whose plight L. W. McCaskill describes as "desperate" in his article on page 33

Photographs by P. Morrison

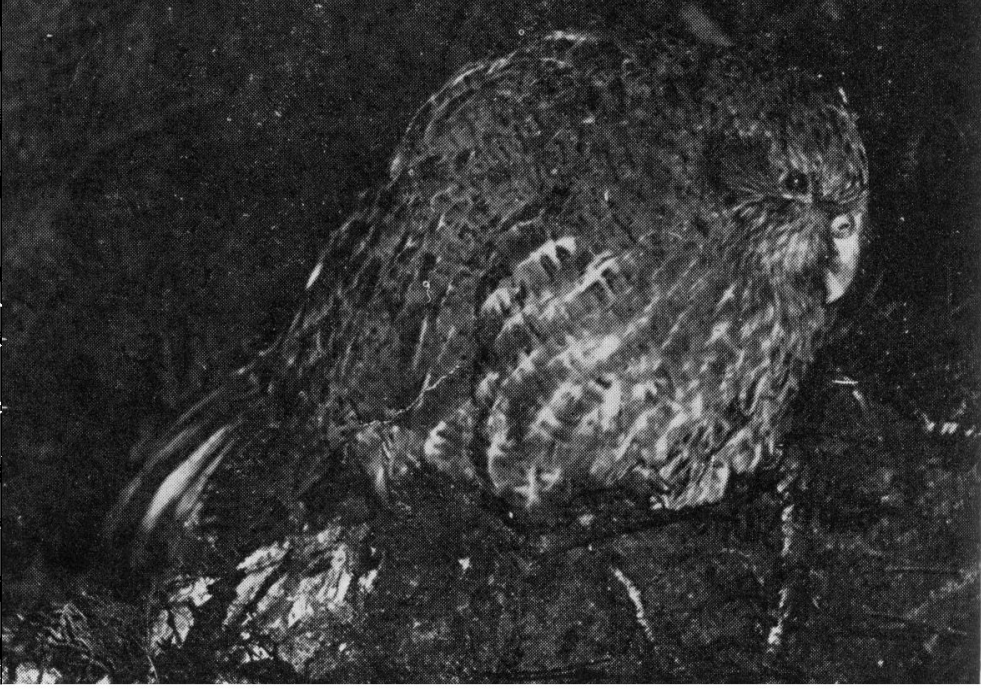

